MAKING CITIZEN-SOLDIERS 

MICHAEL S. NEIBERG

\section{Making Citizen-Soldiers}

ROTC and the Ideology of American Military Service

HARVARD UNIVERSITY PRESS

Cambridge, Massachusetts, and London, England 
Copyright $\odot 2000$ by the President and Fellows of Harvard College All rights reserved

Printed in the United States of America

Second printing, 2001

First Harvard University Press paperback edition, 2001

Library of Congress Cataloging-in-Publication Data

Neiberg, Michael.

Making citizen-soldiers : ROTC and the ideology of American military service / Michael S. Neiberg.

p. cm.

Includes bibliographical references and index.

ISBN 0-674-54312-2 (cloth)

ISBN 0-674-00715-8 (pbk.)

1. United States. Army. Reserve Officers' Training Corps.

2. United States. Air Force ROTC.

3. United States. Naval Reserve Officers Training Corps.

4. United States-Armed Forces-Officers-Training of. I. Title.

U428.5.N45 2000

355.2'232'071173-dc21 99-044354 
To the memory of Ethel Neiberg and Renee Saroff Oliner 
